\title{
Assessment of Greenhouse and Laboratory Screening Methods for Evaluating Potato Foliage for Resistance to Late Blight
}

\author{
Anne E. Dorrance and Debra Ann Inglis, Washington State University, Mount Vernon-Research and Extension \\ Unit, 1468 Memorial Highway, Mount Vernon 98273
}

\begin{abstract}
Dorrance, A. E., and Inglis, D. A. 1997. Assessment of greenhouse and laboratory screening methods for evaluating potato foliage for resistance to late blight. Plant Dis. 81:1206-1213.

Greenhouse and laboratory screening methods for assessing potato foliage for resistance to late blight were compared using 15 cultivars and advanced breeding selections with known field response to late blight. Screening methods included greenhouse inoculation of plants in several age classes, and laboratory assays of detached leaflets, leaf disks, and stem cuttings. Greenhouse inoculation of plants 7 to 11 weeks after planting, near the time of flowering, corresponded best to results obtained in field evaluations, but there were significant differences in disease severity between separate greenhouse tests. This is consistent with variation in late blight severity on a year-to-year basis when cultivars are compared in the field. The greenhouse inoculation method allowed for testing of several components of partial resistance, such as infection efficiency and lesion growth rate, which may exist for each cultivar. Laboratory assays proved less reliable than greenhouse assays for overall ratings of partial resistance, but could be useful for measuring specific components of resistance. Screening evaluations for late blight resistance should include standard cultivars with known reaction to Phytophthora infestans to reference the disease potential within the screening evaluation.
\end{abstract}

Additional keywords: partial resistance, Solanum

Recent potato (Solanum tuberosum L.) breeding efforts in the United States have emphasized resistance to Streptomyces scabies (Thaxt.) Waksman \& Henrici, Alternaria solani (Sorauer), and Verticillium dahliae Kleb. in addition to desirable yield potential and tuber qualities for processing (36). In contrast, screening for resistance to late blight caused by the fungus Phytophthora infestans (Mont.) de Bary has been an essential part of potato cultivar development in many other areas of the world. As a result, numerous screening techniques have been developed for the assessment of resistance to late blight in Solanum germ plasm, and the study of parasitic fitness of $P$. infestans populations. The arrival of aggressive strains of $P$. infestans, including the A2 mating type

Corresponding author: D. A. Inglis

E-mail: dainglis@coopext.cahe.wsu.edu

This work was supported, in part, by the National Potato Council. Plant Pathology New Series no. 0253, project 11D 3461 5123, College of Agriculture and Home Economics Research Center, Washington State University, Pullman.

Accepted for publication 23 July 1997.

Publication no. D-1997-0820-03S

(C) 1997 The American Phytopathological Society
$(18,19,33)$, and the simultaneous loss in effectiveness of a major fungicide (metalaxyl) used in the management of this disease $(9,16)$ have placed a new demand on United States potato breeding programs to develop cultivars with long-lasting, or durable, resistance to late blight. It would be advantageous to utilize previously developed screening techniques, particularly in early stages of selection when a large number of clones need evaluation, and to employ techniques appropriate for selection of partial resistance. Partial resistance or rate-reducing resistance in potatoes is thought to be durable $(5,25,35,52)$. The purpose of this investigation was twofold: (i) to review the methodology currently reported for screening germ plasm for late blight resistance, and (ii) to employ some of the methods on a selected set of cultivars to determine whether known field reactions are validated. Results of these studies are being used to develop rapid greenhouse and laboratory screening techniques to enhance the selection of late blight resistance in germ plasm and future potato cultivars.

\section{LITERATURE REVIEW}

From 1920 to 1950 , single genes or Rgenes for late blight resistance were transferred from Solanum demissum into potato cultivars $(39,50,53)$. This type of resistance was quickly overcome when resistance in the host selected for new virulence loci in the fungus (reviewed by Toxopeus [50],53). This dynamic is typical of plant pathosystems that operate in a gene-forgene system as first described by Flor (11). Hence, potato breeding efforts that incorporate partial or rate-reducing resistance into new commercial cultivars are now widely preferred. While new selections may not be immune, where there is no interaction between the pathogen and the host to any specific race of $P$. infestans, they do limit disease development through a variety of mechanisms. Characters that have been associated with partial resistance include reduced infection efficiency (limitation to infection and penetration), reduced lesion size, and reduced sporulation capacity $(6,27,46,52)$. There are also many sources of partial resistance components to late blight in wild Solanum spp., and several evaluation techniques have been used to identify them $(6,22,37,48)$. In addition, phenotypes similar to partial resistance have been identified in other host systems (55) and reviewed by Parlevliet (35).

The most effective and reliable methods for screening germ plasm are generally accepted to be natural infections or inoculated test plots under field conditions (22). However, this requires a site where late blight epidemics occur reliably year after year, and a $P$. infestans population that is complex not only in regard to virulence loci (sensu Flor; 12), but representative of fungal populations where the potato cultivars will eventually be produced. Such requirements pose a challenge for plant pathologists and breeders. Laboratory or greenhouse screening techniques that rapidly and accurately assess resistance, particularly the effects of partial resistance components on large numbers of seedlings early in the selection process, could be useful and time-saving if they accurately predict future reactions under field epiphytotics.

There are other challenges to consider in the development of germ plasm screening assays for late blight resistance. Tuber infection is a second type of crop loss occurring at the end of a field epidemic. Several studies have reported that tuber and foliage susceptibilities to $P$. infestans are 
not well correlated $(7,14,17,24,26,47)$. Therefore, it is necessary to utilize screening assays which will assess resistance in tubers and foliage separately.

The resistance response may be influenced by many variables. Stewart (40) reported that age of the plant, spore concentration, and method of inoculation can all influence the resistance response in foliage. She indicated that plants in bud or early stages of flowering expressed resistance consistently between tests. Fry and Apple (13) found the rate of the epidemic was influenced by the age of the plants, and disease progression did not occur as fast in intermediate-aged plants when compared to older plants. Reactions were also influenced by maturity characteristics of the cultivars. Cultivars with longer vegetative (late-maturing) periods are generally more resistant to late blight, presumably because the foliage is physiologically younger than shorter season (earlymaturing) cultivars. Carnegie and Colhoun (4) reported that changes in disease reaction were dependent on plant age and leaf position. Resistant cultivars were susceptible as young plants, but susceptibility decreased prior to flowering and increased during senescence. Other factors that have been reported to affect the expression of partial resistance include day length, plant nutrition (46), and inoculum densities (28).

Tables 1 and 2 outline some of the seedling, detached leaflet, detached leaf, and leaf disk methods that have been utilized to identify susceptible and resistant germ plasm in early screening efforts for late blight resistance. The seedling assay has been utilized to assess resistance or susceptibility to late blight $(31,51)$, parasitic fitness of $P$. infestans isolates (26), genetic components that comprise resistance, and to identify the gene action in potential parents $(1,32,44)$. Umaerus (51) measured infection efficiency by limiting the incubation period following seedling inoculations, and reported that late blight outbreaks are delayed under field conditions in potato cultivars having low infection efficiency. This resistance component is, however, not closely associated with late maturity. Caligari et al. (2) reported seedling blight screens were useful in eliminating susceptible material from a population and found greenhouse assays correlated well with field tests. Seedlings scored for leaf lesion size, leaf lesion frequency, petiole lesion size, petiole lesion frequency, stem lesion size, and stem lesion frequency plus an overall rating were used to identify potential parental material with general combining ability (GCA). Parents with the highest GCA often expressed high levels of partial resistance. Bradshaw et al. (1) used the seedling assay to measure GCA and specific combining ability (SCA) effects in progenies from a diallel cross. They reported that R-gene resistance could be separated from partial resistance because the GCA would increase for a partially resistant parent in all progenies tested. R-genes tend to increase SCA, while partial resistance contributes to the magnitude of GCA when compatible virulence genes are present in the fungal population.

Hodgson (23) was the first to report a screening assay using leaf disks. The advantage to this technique is that plants can be used in more than one assay and challenged with more than one isolate. Leonard-Schippers et al. (30) were able to map quantitative trait loci for late blight resistance using this technique. Detached leaflet assays are routinely used to identify virulence loci in $P$. infestans populations $(9,37,49)$. Tooley $(48)$ demonstrated variation in the resistance response among a collection of Solanum verrucosum PI's using the detached leaflet method. However, Hodgson (23) cautioned that plants and leaves to be used in screening evaluations must be the same age, and tests must be made when the plants are at the same stage of growth and when they are normally attacked in the field. Stewart (40) identified two types of responses in potato differentials when inoculated with $P$. infestans in order to identify virulence genotypes: lesions produced at all plant ages and spore concentrations, and a variable response resulting from plant age, spore concentration, and inoculation method ranging from immunity to spreading sporulating lesions.

Table 1. Summary of some greenhouse (GH) methods used in screening seedlings of Solanum germ plasm and potato cultivars for foliar late blight resistance

\begin{tabular}{|c|c|c|c|c|}
\hline Plant material; age; size & Inoculum & Environment $^{\mathrm{z}}$ & Rating & Citation \\
\hline 2 plants/clone; prior to flowering; $12 \mathrm{~cm}$ pots & $\begin{array}{l}\text { Sprayed sporangia/zoospore } \\
\text { suspension }\end{array}$ & $\begin{array}{l}7 \mathrm{~d} \text { at } 15-18^{\circ} \mathrm{C} ; \text { high } \\
\text { humidity; shaded GH }\end{array}$ & $\begin{array}{l}1-9 \text { scale; } 1=\text { susceptible, } \\
9=\text { resistant }\end{array}$ & 31 \\
\hline True seed; $6-8$ weeks after sowing & $\begin{array}{l}5 \times 10^{4} \text { sporangia/ml; } \\
\text { complex race } \\
1,2,3,4,5,7,8,9,10,11\end{array}$ & $\begin{array}{l}24 \mathrm{~h} \text { at } 15-18^{\circ} \mathrm{C} \text {; } \\
\text { high humidity; } \\
\text { followed by } 6 \mathrm{~d} \text { at } 15^{\circ} \mathrm{C}\end{array}$ & $\begin{array}{l}1-4 \text { scale based on percent } \\
\text { leaf area with blight; } \\
1=>50 \%, 4=\text { little to } \\
\text { no blight }\end{array}$ & 3,41 \\
\hline True seed; $15-20 \mathrm{~cm}$ height & $\begin{array}{l}\text { Sprayed with } \\
4,000 \text { sporangia/ml }\end{array}$ & $\begin{array}{l}16-18 \mathrm{~h} \text { at high humidity; } \\
\text { rated after } 7 \mathrm{~d}\end{array}$ & $\begin{array}{l}\text { Susceptible or resistant; } \\
\text { no. of lesions/rate } \\
\text { of spread }\end{array}$ & 44 \\
\hline $\begin{array}{l}\text { Fitness test for isolates on cv. Norchip; } \\
4-8 \text { weeks old }\end{array}$ & $\begin{array}{l}50 \mu \mathrm{l} \text { of } 25,000 \text { sporangia } / \mathrm{ml} \\
\text { on adaxial surface of } \\
4 \text { subterminal leaflets }\end{array}$ & $\begin{array}{l}24 \text { h dark; } 100 \% \mathrm{RH} \text {; lesions } \\
\text { allowed to expand for } 48 \mathrm{~h} \text {; } \\
\text { followed by } 100 \% \mathrm{RH} \\
\text { to induce sporulation }\end{array}$ & & 49 \\
\hline True seed; $20 \mathrm{~cm}$ height; 8 weeks old & $\begin{array}{l}\text { Sprayed with an aerosol } \\
\text { delivery, sporangia and } \\
\text { zoospores }\end{array}$ & $\begin{array}{l}\text { Automatic mist; } \\
\text { shaded GH; } 7 \text { d }\end{array}$ & $\begin{array}{l}\text { Scored for size and } \\
\text { frequency of lesions on } \\
\text { leaves and petioles; overall } \\
\text { score 1-9 }\end{array}$ & 32 \\
\hline $12-15$ in tall; $6-10$ true leaves & $\begin{array}{l}\text { Atomized } 3,300,10,000 \text {, } \\
\text { or } 30,000 \text { sporangia/ml; } \\
10 \mathrm{ml} \text { per plant }\end{array}$ & $\begin{array}{l}12 \mathrm{~h} \text { at } 21^{\circ} \mathrm{C} \\
\text { high humidity }\end{array}$ & No. of lesions per leaf & 27 \\
\hline True seed; 4-6 weeks old; $4-5$ true leaves & $\begin{array}{l}\text { Race } 1,2,3,4 ; \\
150 \times 10^{4} \text { zoospores } / \mathrm{mm}^{3} ; \\
30 \mathrm{ml} / 1000 \text { plants }\end{array}$ & $\begin{array}{l}15 \mathrm{~h} \text { at } 15-17^{\circ} \mathrm{C} \\
100 \% \mathrm{RH} \\
\text { rated after } 4-5 \mathrm{~d}\end{array}$ & $\begin{array}{l}\text { Presence/absence } \\
\text { of lesions }\end{array}$ & 51 \\
\hline Minitubers; $45 \mathrm{~cm}$ tall & Complex race, zoospores & $100 \% \mathrm{RH}$ & $\begin{array}{l}\% \text { disease compared to } \\
\text { controls; scale } 1-9\end{array}$ & 29 \\
\hline True seed; 5-6 weeks old & $\begin{array}{l}5 \times 10^{4} \text { zoospores } / \mathrm{ml} ; \\
2 \text { isolates race } 1,4,10,11 \\
\& \text { race } 1,2,3,4,7\end{array}$ & $7 \mathrm{~d}$ & $\begin{array}{l}1-4 \text { scale } 1=>50 \% \\
\text { disease, } 4=<10 \% \text { disease }\end{array}$ & 1 \\
\hline
\end{tabular}

${ }^{\mathrm{z}} \mathrm{d}=$ day; $\mathrm{RH}=$ relative humidity. 
The existence of new immigrant strains of $P$. infestans, and metalaxyl-resistant $P$. infestans populations throughout the United States $(9,18,19)$, have placed a renewed emphasis on defining durable resistance to late blight for future cultivars. There is a continuing need for greenhouse and laboratory tests that could expedite cultivar and germ plasm evaluation for late blight resistance particularly if partial resistance components could be measured.

\section{MATERIALS AND METHODS}

Field evaluations. The western Washington $P$. infestans population has been reported to consist of complex races $(8,9,20)$. Virulence factors 9 and 11 have not been identified to date and, in 1995 , virulence factor 10 was very rare (A. E. Dorrance and D. A. Inglis, unpublished data). Only two genotypes of $P$. infestans, US-6 and US-11, have been detected, 1990 to $1996(18,24)$. Both are metalaxyl-insensitive and A1 mating type.

The field design used in this study was reported earlier (24). Cultivars were planted in a randomized complete block design, with three replications each consisting of 10 plants per plot. Plots consisted of four record rows bordered on the outside by potato cultivar White Rose, which is intermediate in resistance to late blight (Table 3). In 1996, cultivars Norchip and Alpha were planted in a neighboring trial in four plant rows. Once the onset of disease occurred, naturally infested leaves from an adjoining field trial were moved along the border rows to ensure uniform inoculum dosage. Late blight was recorded weekly (percent blighted foliage per plot) throughout the 1995 and 1996 growing seasons. Percentages were used to calculate area under the disease progress curve (AUDPC). The AUDPC values were analyzed using the PROC RANK procedure in SAS (SAS Institute, Cary, NC). Correlation coefficients were calculated using the PROC CORR procedure from the ranked mean response from each greenhouse and laboratory assay and the ranked AUDPC means for each cultivar.

Inoculum production. One isolate, $P$. infestans 95WWA (US-11, sensu Goodwin and Fry; 24) with virulence genes 1,2,4,5,7 (Dorrance and Inglis, unpublished data) was used in all experiments. Of the $P$. infestans isolates we have identified from western Washington to date, 95WWA is one of the most complex race types. Inoculum was produced on potato leaflets, tuber slices, or rye agar. A 40- $\mu 1$-drop of a sporangial suspension $\left(1 \times 10^{4}\right)$ was placed on potato leaflets in moist chambers and incubated at $20^{\circ} \mathrm{C}$ under $12 \mathrm{~h}$ light (Philips Fluorescent TL70 or Philips 60W Fluorescent F48T12 and Philips Tungsten $60 \mathrm{~W}$ ) for 7 days. A 5-mm colonized plug was placed on the center of a potato tuber slice or rye agar plate and incubated at $20^{\circ} \mathrm{C}$ in the dark for 5 to 7 days. Potato leaflets, tuber slices, and rye agar plates were washed with distilled water, sporangia counted with a hemacytometer, and final concentrations were adjusted according to the assay protocol described below.
Greenhouse cultivation. Potato cultivars and advanced breeding selections used in this study are shown in Table 3. Tubers of potato cultivars were received from the USDA-ARS, University of Idaho Aberdeen Research and Extension Center. Approximately $500 \mathrm{ml}$ of Sunshine mix (SunGro Horticulture, Bellevue, WA) was placed in 16-cm-diameter pots, one eye was cut approximately 10 to $15 \mathrm{~cm}$ in diameter from a tuber, the seedpiece was covered with mix, and more mix was added as the sprouts developed. Plants were fertilized when watered with 100 ppm N-P-K and 2.5 ppm Peters soluble trace element mix (Scotts Sierra Horticultural Products Co., Marysville, OH). Supplemental fertilizer (23N-19P-17K) with RAPID GRO (San Ramon, CA) was applied as needed. Supplemental lighting from high intensity lights (Sylvania 1000, Danvers, MA) provided a 12-h light:dark cycle.

Greenhouse seedling/whole plant assay. Eleven cultivars were planted on 14 April and 15 May, 14 cultivars on 31 May, and 16 cultivars on 14 June and 1 July. Three plants from each cultivar and planting date were inoculated with a $P$. infestans sporangia suspension $\left(8 \times 10^{3} / \mathrm{ml}\right)$ with an atomizer on 6 June, 6 July, 1 August, and 1 September. Immediately after inoculation, plants were transferred to a mist chamber where they were kept under $100 \%$ relative humidity for 2 days at temperatures ranging from 10 to $22^{\circ} \mathrm{C}$. Ratings of infection were begun 4 or 5 days later. To induce sporulation, plants were placed in the mist

Table. 2. Summary of laboratory methods utilizing leaf disks (LD), detached leaflets (LL), or detached leaves (LV) in screening Solanum germ plasm and potato cultivars for foliar resistance to late blight

\begin{tabular}{|c|c|c|c|c|}
\hline Plant material; age & Inoculum & Environment ${ }^{y}$ & Rating & Citation \\
\hline $\begin{array}{l}\text { LL; estimated resistance to invasion; } \\
\text { flowering stage }\end{array}$ & $\begin{array}{l}\text { Standardized zoospore } \\
\text { suspension; 60-200 per drop }\end{array}$ & $\begin{array}{l}5 \mathrm{~d} \text { at } 15^{\circ} \mathrm{C} ; 95-100 \% \\
\text { humidity; continuous light }\end{array}$ & Measured diameter of lesions & 34 \\
\hline LL; flowering stage & $\begin{array}{l}4 \text { isolates; } 1 \text { drop of } \\
5,000-10,000 \text { zoospores }\end{array}$ & $3 \mathrm{~d}$ & $\begin{array}{l}\text { Hypersensitive response; } \\
\text { sporulation }\end{array}$ & 37 \\
\hline $\begin{array}{l}\text { LL; youngest fully expanded pair of } \\
\text { leaflets, abaxial surface }\end{array}$ & $\begin{array}{l}\text { Zoospores, spray and drop; } \\
\text { after } 24 \mathrm{~h} \text { disks inverted }\end{array}$ & $\begin{array}{l}15^{\circ} \mathrm{C} \text {; high humidity; } \\
16 \text { light }\end{array}$ & $\begin{array}{l}1-3: 1=\text { no symptoms, } \\
2=\text { spreading but no sporulation, } \\
3=\text { spreading sporulating lesion }\end{array}$ & 40 \\
\hline $\begin{array}{l}\text { LL; } 4 \text { weeks after transplanting; } \\
3 \text { leaflets/plant; abaxial surface }\end{array}$ & $40 \mu \mathrm{l}$ of 50,000 sporangia/ml & Plastic boxes; $7 \mathrm{~d}$ at $18^{\circ} \mathrm{C}$ & $\begin{array}{l}\text { Sporulation rated } 0-3 \text { scale; } \\
\% \text { area colonized }\end{array}$ & 48 \\
\hline $\begin{array}{l}\text { LL; lateral leaflets of the first terminal } \\
\text { pair }\end{array}$ & $\begin{array}{l}2,500 \text { sporangia/ } / 50 \mathrm{~mm}^{3} \text { one } \\
\text { drop/leaflet near midrib }\end{array}$ & $\begin{array}{l}\text { Plastic trays; } 6 \mathrm{~d} \text { at } 16^{\circ} \mathrm{C} \text {; } \\
\text { high humidity; } 16 \mathrm{~h} \text { light }\end{array}$ & $\begin{array}{l}3 \text { categories based on } \\
\text { lesion development }\end{array}$ & 43 \\
\hline $\begin{array}{l}\text { LL; } 4 \text { weeks; R- gene differential } \\
\text { genotypes }\end{array}$ & $\begin{array}{l}50 \mu \mathrm{l} \text { of } 40,000 \text { sporangia/ml or } \\
\text { a } 4 \mathrm{~mm} \text { mycelial plug }\end{array}$ & $5 \mathrm{~d}$ at $18-20^{\circ} \mathrm{C}$ & Susceptible if sporulating & 9 \\
\hline $\mathrm{LL}^{\mathrm{z}}$ & $\begin{array}{l}10,000 \text { sporangia/ml, atomized } \\
\text { onto surface }\end{array}$ & $5 \mathrm{~d}$ at $18^{\circ} \mathrm{C}$; high humidity & $\begin{array}{l}\text { Presence of lesion } \\
\text { and sporulation }\end{array}$ & 15 \\
\hline $\mathrm{LD}, 15 \mathrm{~mm}$ & $50-100$ zoospores $/ 45 \mu \mathrm{l}$ & $7 \mathrm{~d}$ at $20^{\circ} \mathrm{C}$; high humidity & Presence/absence sporulation & 23 \\
\hline $\begin{array}{l}\mathrm{LD} ; 8 \mathrm{~mm} \text { in diameter; adaxial surface; } \\
8 \mathrm{LD} \text { per genotype; collected from } \\
\text { same or directly adjacent leaf; } \\
\text { third internode from top; } \\
\text { same plant used for all experiments }\end{array}$ & $\begin{array}{l}3-10 \mu \mathrm{l} \text { of } \\
30,000 \text { sporangia } / \mathrm{ml} \text { and } \\
40,000 \text { zoosporangia/ml }\end{array}$ & $3-4 \mathrm{~d}$ at $17^{\circ} \mathrm{C} ; 14 \mathrm{~h}$ light & & 30 \\
\hline LD; 100 disks & Zoospores, sporangia & $7 \mathrm{~d}$ & Mycelial growth and sporulation & 54 \\
\hline LV & & $7 \mathrm{~d}$ at $18^{\circ} \mathrm{C} ; 100 \% \mathrm{RH}$ & & 21 \\
\hline
\end{tabular}

y d = day; $\mathrm{RH}=$ relative humidity.

${ }^{\mathrm{z}}$ Assay used to detect redistribution of air-applied fungicides. 
chambers for $24 \mathrm{~h}, 6$ to 8 days after inoculation. Ratings included: (i) overall rating of 1 to 9 , where $9=$ resistant and $1=$ susceptible (based on percent foliage with lesions, detailed description in Malcolmson (31), (ii) number of lesions per plant, and (iii) percent plant diseased. Ratings were taken periodically over a period of 1 to 2 weeks or until the most susceptible plant died. Ratings from each experiment were pooled and analyzed for differences between experiments, among cultivars and plant ages, and interactions between cultivars and plant age, cultivars and experiments, cultivars and plant age, and experiments using SAS. Data were sorted by test, cultivar, and plant age. Cultivar mean late blight ratings were analyzed using Fisher's least-significant-difference test (LSD) for each experiment and plant age.

Laboratory detached leaflet and leaf disk assays. The two top fully expanded leaves from 3 to 4 plants were collected from 6- to 8-week-old plants. Side leaflets were detached with scissors and used for detached leaflet assay. Leaf disks were cut with a cork borer (15-mm) from the primary leaflet on both sides of the vein. Four leaflets and 3 to 4 disks per cultivar were placed in the lids of inverted, large $(15-\mathrm{cm})$ petri dishes containing $25 \mathrm{ml}(1.5 \%)$ water agar (49). Three plates per cultivar were kept at $20^{\circ} \mathrm{C}$ with $12 \mathrm{~h}$ light in a growth chamber (Philips 60W Fluorescent F48T12 and Philips $60 \mathrm{~W}$ incandescent) or in an incubator, also at $20^{\circ} \mathrm{C}$ and $12 \mathrm{~h}$ light (Philips Fluorescent TL70), for 7 days. Percent colonization by the fungus was determined at 5, 6, and 7 days after inoculation with a 40- $\mu$ l droplet of 4,000 sporangia per ml. Statistical analysis was done on the final reading of percent colonization and the number of leaflets and leaf disks that developed blight lesions. This assay was repeated three times. The data from the three experiments for both detached leaflets and leaf disks were pooled and analyzed for differences between experiments, detached leaflets, and leaf disks for the cultivars. The mean percent late blight of the detached leaflets and leaf disks was then analyzed separately for each experiment using LSD.

Laboratory stem assay. Three aboveground stems from each of 14 cultivars were cut to 100 to $140 \mathrm{~mm}$ in length from 4- to 6-week-old potato plants 6 July and 16 July, and immediately placed in distilled water and designated Test 1 and Test 2 . The test was repeated with 16 cultivars on 16 August and designated Test 3. Each stem was transferred to a 50-ml tube containing a nutrient solution of $660 \mathrm{ml}$ distilled water, $4.5 \mathrm{~g}$ sucrose, and $0.3 \mathrm{~g}$ Peters Fertilizer 20-20-20, (Scotts Sierra Horticultural Products Co., Marysville $\mathrm{OH} ; 15$ ). Filter paper squares $\left(5 \mathrm{~mm}^{2}\right)$ were soaked in a sporangial suspension of 1.4 to $1.5 \times$ $10^{4}$ sporangia/ml for $30 \mathrm{~min}$. One filter paper square was placed on each stem approximately 30 to $50 \mathrm{~mm}$ from the top of the cutting with forceps. Tubes with stem cuttings were placed in a randomized block design in a growth chamber at $20^{\circ} \mathrm{C}$ with $12 \mathrm{~h}$ light (Philips 60W Fluorescent F48T12 and Philips 60W incandescent) for 7 days. Nutrient solution was added to the tubes as needed to prevent desiccation of stems. Presence of stem blight was noted and lesion length was measured. Lesion length data were pooled from the three experiments and analyzed by the general linear model procedure (GLM) of SAS for experiments and cultivars. Cultivar mean separation using LSD was completed on the experiments separately.

\section{RESULTS}

Field evaluations. Potato cultivars and advanced selections used for this study and their field reactions to late blight are shown in Table 3. Members of this group have had a similar reaction to late blight when ranked against each other at Mount Vernon and in other locations in the US $(24,42,45,47,53)$. Field analysis near Mount Vernon, Washington in 1993 to 1996 indicated that Elba, COO83008-1, and White Rose were less susceptible to late blight than Russet Burbank; Kennebec and Ranger Russet were similar in susceptibility; and Shepody and Russet Norkotah were more susceptible than Russet Burbank. Bzura, Brador, and Brodick were the most resistant of those tested.

Greenhouse seedling/whole plant assay. The data for each greenhouse inoculation were pooled and analyzed. There were highly significant differences for cultivars $(P=0.0001)$, ages $(P=0.0001)$, experiments $(P=0.0001)$, cultivar by age $(P=$ $0.0001)$, and cultivar by test interaction $(P$ $=0.0001)$. Hence, each test and cultivar age experiment was analyzed separately (Table 4).

Differences in greenhouse experiments were attributed mainly to variation in overall disease severity due to different environmental conditions in June, July, and August. For example, mean disease rating of 4- to 6-, 7- to 8-, and 9- to 11-week-old plants in three tests were $7.3,8.2$, and 4.5 ; 6.6, 7.9, and 4.1; and, 7.7, 4.4, and 4.7, respectively. Temperatures in the mist chambers were higher $\left(13\right.$ to $\left.17^{\circ} \mathrm{C}\right)$ during the August test compared to the other three inoculations, where temperatures sometimes fell below $10^{\circ} \mathrm{C}$ following inoculation.

Plants of Alpha, Russet Burbank, Elba, and Kennebec had more foliage blight following inoculation on 4- to 6-week-old than on 7- to 8-week-old plants in the August test. Russet Norkotah, Norchip, Ranger Russet, Shepody, A84118-3, and

Table 3. Area under the disease progress curve (AUDPC) values for 13 potato cultivars and 2 advanced selections obtained from field studies near Mount Vernon, Washington, and used to assess reliability of greenhouse and laboratory screening methods for late blight resistance

\begin{tabular}{|c|c|c|c|c|c|}
\hline \multirow[b]{2}{*}{ Potato cultivar and advanced selections } & \multirow[b]{2}{*}{ Reported resistance $^{\mathrm{z}}$} & \multicolumn{4}{|c|}{ AUDPC $^{y}$} \\
\hline & & 1993 & 1994 & 1995 & 1996 \\
\hline Bzura & $\mathrm{R}$ genes and $\mathrm{FR}$ & $\ldots$ & $\ldots$ & $304 \mathrm{a}$ & $225 \mathrm{a}$ \\
\hline Brador & $R$ genes and FR & $\ldots$ & $\ldots$ & $1,050 \mathrm{bc}$ & $465 \mathrm{~b}$ \\
\hline Brodick & General FR & $\ldots$ & $\ldots$ & & $606 \mathrm{~b}$ \\
\hline A84118-3 & unknown & $\ldots$ & $\ldots$ & $890 \mathrm{~b}$ & $1,202 \mathrm{c}$ \\
\hline Alpha & FR & & $\ldots$ & & $1,285 \mathrm{c}$ \\
\hline Elba & FR & 527 a & $135 \mathrm{a}$ & $880 \mathrm{~b}$ & $1,498 \mathrm{~d}$ \\
\hline COO83008-1 & unknown & $\ldots$ & $362 \mathrm{a}$ & $915 \mathrm{~b}$ & $1,600 \mathrm{~d}$ \\
\hline White Rose & IS & $1,060 \mathrm{~b}$ & $834 \mathrm{bc}$ & $\ldots$ & $1,539 \mathrm{~d}$ \\
\hline Kennebec & MR & & $247 \mathrm{a}$ & $1,000 \mathrm{~b}$ & $1,674 \mathrm{de}$ \\
\hline Russet Burbank & IS & $1,035 \mathrm{~b}$ & $650 \mathrm{~b}$ & $1,243 \mathrm{cde}$ & $1,776 \mathrm{ef}$ \\
\hline Ranger Russet & $\mathrm{S}$ & $1,101 b c$ & 389 a & $1,108 \mathrm{bcd}$ & $1,890 \mathrm{f}$ \\
\hline Shepody & $\mathrm{S}$ & $1,169 \mathrm{bc}$ & $807 \mathrm{bc}$ & $1,303 \mathrm{de}$ & $1,868 \mathrm{f}$ \\
\hline Red LaSoda & $\mathrm{S}$ & $\ldots$ & $1,030 \mathrm{c}$ & $\ldots$ & $\ldots$ \\
\hline Norchip & HS & $\ldots$ & $\ldots$ & $\ldots$ & $2,189 \mathrm{~b}$ \\
\hline Russet Norkotah & $\mathrm{S}$ & $1,214 \mathrm{c}$ & $1,423 \mathrm{~d}$ & $1,377 \mathrm{e}$ & $2,479 \mathrm{a}$ \\
\hline
\end{tabular}

${ }^{y}$ AUDPC calculated from $\%$ blighted foliage; ranks determined according to PROC RANK procedure in SAS (SAS Institute, Cary, NC); means followed by the same letter in a column do not differ significantly at $P \leq 0.05$ according to Fisher's least significant difference test; ... designates that there is no data for that cultivar in that year.

${ }^{\mathrm{z}}$ Ratings for resistance: FR = field resistant, $\mathrm{MR}=$ moderately resistant, IS = intermediate susceptible, $\mathrm{S}=$ susceptible, and HS = highly susceptible $(22,24,42,45,47,53)$. 
CO083008-1 had more foliage blight 7 to 8 weeks than 4 to 6 weeks after planting in the August test. Disease reactions were similar, though, for most cultivars inoculated when either 7 to 8 or 9 to 11 weeks old. Plants that were 15 weeks old or older senesced in the mist benches and the data was considered unreliable for inclusion in the final analysis.

Plants inoculated at 7 to 8 weeks and 10 to 12 weeks in age in the greenhouse corresponded most closely in resistance ratings to the field rankings for both percent foliage blight (data not shown) and Malcolmson's (31) late blight rating scale. The 7- to 8 -week-old plants in our greenhouse study were flowering or had just completed the flowering stage. The number of lesions that developed on the cultivars following inoculations was not related to field AUDPC (data not shown). In general, resistant cultivars developed fewer lesions than intermediate and susceptible cultivars which varied in number of lesions.

Laboratory detached leaflet and leaf disk assays. Data from two of the experiments were pooled and analyzed for differences in percent leaf colonized among experiments, cultivars, detached leaflets, and leaf disks. There were significant differences among the experiments $(P=$ $0.0001)$, cultivars $(P=0.0001)$, and detached leaflets versus leaf disks $(P=$ 0.0004). For each test, leaflets and leaf disks were then analyzed separately (Table 5). Again, different amounts of disease developed between the experiments; the mean percent disease was 45.9, 30.6, and 12.7 for detached leaflets and 28.6, 73.5, and 19.9 for the leaf disks in tests 1,2 , and 3 , respectively. The third test (data not shown) followed an insecticide treatment of resmethrin which is reported to inhibit foliar infection (38).

The cultivars did not respond the same way within each experiment or between experiments in regard to the amount of blight on the detached leaflets compared to the leaf disks. For example Russet Burbank had 82.5 and $27.6 \%$ colonization in the detached leaflet and 8.3 and $96.9 \%$ in leaf disk assays (Table 5). However, Bzura, Brador, and Brodick means ranged from 0.0 to $10.3 \%$ colonization, indicating high levels of resistance. The rest of the cultivars were all colonized by $P$. infestans to some extent, indicating susceptibility. Due to high variability between experiments, detached leaflet and leaf disk assays when read 7 days following inoculation could only reliably separate cultivars into two groupings: resistant or susceptible.

Laboratory stem assay. The data from all three tests were pooled and analyzed. Test 1 and 2 were not significantly different from one another $(P=0.96)$. Test 3 differed from the first two based mainly on the change in reaction of cultivar Elba and longer lesion length for all cultivars. In the first two assays, Elba failed to develop stem lesions, but in the last assay stem lesions developed. The results from each experiment are presented in Table 6. These results are similar to the foliage response in that the cultivars fall into similar groupings of resistant and susceptible, but there is considerable variability of the individual rank for each cultivar. For example, Kennebec had small mean lesion length of $8.0 \mathrm{~mm}$ in test 2, indicating resistance, but in test 3 was susceptible, with lesion length of $46.3 \mathrm{~mm}$.
Correlation of assays. Correlation coefficients for comparisons with the ranked means of the field 1996 AUDPC (the most complete set of cultivars and advanced selections) and with the ranked means from each greenhouse and laboratory assay are presented in Table 7. In most cases, the greenhouse inoculation results for plants inoculated 7 to 11 weeks after planting were more highly correlated $(r \geq-0.84)$ with the field AUDPC values from 1996 than were results for plants inoculated 4 to 6 weeks after planting ( $r$ values ranged from -0.57 to -0.82 ) and all of the laboratory assays ( $r$ values ranged from 0.44 to 0.77 ). The one exception was in the July greenhouse inoculation of plants 7 to 8 weeks old, in which the correlation coefficient was the lowest $(r=-0.28)$. In this trial, one plant of the cultivar Shepody may have escaped disease during the inoculation process, and Elba had a lower disease rating than expected. The final mean rating (Malcolmson's scale, 31) for this assay was also higher than for the other inoculations. This illustrates that greenhouse assays must reach a sufficiently high disease severity level to provide a reliable indication of field response. The laboratory assays for the detached leaflet, leaf disk, and stem assays were variable in their correlation with the field response (Table 7).

\section{DISCUSSION}

The above assays demonstrate possible ways to assess potato foliage and stems for resistance to $P$. infestans, and are validated by established field responses of the cultivars tested. Each laboratory and greenhouse assay separated cultivars into resistant and susceptible groups, although

Table 4. Greenhouse ratings ${ }^{\mathrm{x}}$ of late blight foliage resistance for 13 potato cultivars and 2 advanced selections in three age classes from separate inoculation experiments

\begin{tabular}{|c|c|c|c|c|c|c|c|c|c|c|}
\hline \multirow[b]{2}{*}{ Cultivar } & \multicolumn{3}{|c|}{ 4- to 6-week-old plants ${ }^{y}$} & \multicolumn{3}{|c|}{ 7- to 8-week-old plants } & \multicolumn{4}{|c|}{ 9- to 11-week-old plants } \\
\hline & $\begin{array}{l}\text { June } \\
16 \text { days }^{z}\end{array}$ & $\begin{array}{l}\text { July } \\
8 \text { days }\end{array}$ & $\begin{array}{l}\text { August } \\
7 \text { days }\end{array}$ & $\begin{array}{l}\text { June } \\
16 \text { days }\end{array}$ & $\begin{array}{l}\text { July } \\
8 \text { days }\end{array}$ & $\begin{array}{l}\text { August } \\
7 \text { days }\end{array}$ & $\begin{array}{l}\text { July } \\
8 \text { days }\end{array}$ & $\begin{array}{c}\text { August (9 week) } \\
7 \text { days }\end{array}$ & $\begin{array}{c}\text { August (11 week) } \\
7 \text { days }\end{array}$ & $\begin{array}{l}\text { September } \\
15 \text { days }\end{array}$ \\
\hline Bzura & & $9.0 \mathrm{a}$ & $9.0 \mathrm{a}$ & $\ldots$ & $\ldots$ & $8.7 \mathrm{a}$ & $\cdots$ & $8.3 \mathrm{a}$ & $\cdots$ & $9.0 \mathrm{a}$ \\
\hline Brador & $9.0 \mathrm{a}$ & $9.0 \mathrm{a}$ & $9.0 \mathrm{a}$ & $9.0 \mathrm{a}$ & $9.0 \mathrm{a}$ & $8.7 \mathrm{a}$ & $9.0 \mathrm{a}$ & $8.7 \mathrm{a}$ & $9.0 \mathrm{a}$ & $9.0 \mathrm{a}$ \\
\hline Brodick & & $9.0 \mathrm{a}$ & $9.0 \mathrm{a}$ & & . & $9.0 \mathrm{a}$ & . & $9.0 \mathrm{a}$ & & $9.0 \mathrm{a}$ \\
\hline A84118-3 & $7.5 \mathrm{a}$ & $8.3 \mathrm{abc}$ & $4.7 \mathrm{bcd}$ & $7.7 \mathrm{ab}$ & $8.3 \mathrm{abc}$ & $3.0 \mathrm{cde}$ & $8.3 \mathrm{ab}$ & $6.0 \mathrm{~b}$ & $7.0 \mathrm{ab}$ & $8.0 \mathrm{ab}$ \\
\hline Alpha & $\ldots$ & & $3.0 \mathrm{cdef}$ & 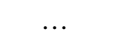 & & $3.7 \mathrm{bcd}$ & & - - & & $6.5 \mathrm{bc}$ \\
\hline Elba & $\ldots$ & $8.3 \mathrm{abc}$ & $2.0 \mathrm{ef}$ & ( & $7.0 \mathrm{e}$ & $5.3 \mathrm{~b}$ & $7.7 \mathrm{bc}$ & $4.7 \mathrm{bc}$ & $4.7 \mathrm{bcd}$ & $4.2 \mathrm{de}$ \\
\hline COO83008-1 & $7.7 \mathrm{a}$ & $7.0 \mathrm{~d}$ & $6.0 \mathrm{~b}$ & $7.5 \mathrm{ab}$ & $8.7 \mathrm{ab}$ & $4.0 \mathrm{bc}$ & $8.3 \mathrm{ab}$ & $3.7 \mathrm{~cd}$ & $7.0 \mathrm{ab}$ & 5.7 cde \\
\hline White Rose & $8.0 \mathrm{a}$ & $8.0 \mathrm{bc}$ & $5.3 \mathrm{bc}$ & $6.7 \mathrm{bc}$ & $7.5 \mathrm{de}$ & $4.0 \mathrm{bc}$ & $7.7 \mathrm{bc}$ & $5.0 \mathrm{bc}$ & $5.3 \mathrm{bc}$ & $5.7 \mathrm{cde}$ \\
\hline Kennebec & $\ldots$ & $8.7 \mathrm{ab}$ & $2.0 \mathrm{ef}$ & $\ldots$ & $7.0 \mathrm{c}$ & $4.0 \mathrm{bc}$ & $7.0 \mathrm{~cd}$ & $3.3 \mathrm{cde}$ & $5.0 \mathrm{bcd}$ & $5.5 \mathrm{cde}$ \\
\hline \multicolumn{11}{|l|}{ Russet } \\
\hline Burbank & $7.3 \mathrm{a}$ & & $1.3 \mathrm{f}$ & $6.7 \mathrm{bc}$ & $7.3 \mathrm{de}$ & $2.3 \mathrm{cde}$ & $7.3 \mathrm{~cd}$ & $2.3 \mathrm{def}$ & $3.3 \mathrm{cde}$ & $5.3 \mathrm{cde}$ \\
\hline Ranger Russet & $5.7 \mathrm{a}$ & $7.7 \mathrm{~cd}$ & $4.7 \mathrm{bcd}$ & $5.0 \mathrm{c}$ & 7.7 cde & $3.0 \mathrm{cde}$ & $7.3 \mathrm{~cd}$ & $1.3 \mathrm{f}$ & $3.5 \mathrm{cde}$ & $5.2 \mathrm{cde}$ \\
\hline Shepody & $6.3 \mathrm{a}$ & $7.7 \mathrm{~cd}$ & 4.0 bcde & $5.0 \mathrm{c}$ & $8.3 \mathrm{abc}$ & $2.0 \mathrm{cde}$ & $7.0 \mathrm{~cd}$ & $2.0 \mathrm{def}$ & $1.0 \mathrm{e}$ & $4.7 \mathrm{cde}$ \\
\hline Red LaSoda & $7.3 \mathrm{a}$ & $8.0 \mathrm{bc}$ & 4.3 bcde & $6.3 \mathrm{c}$ & 7.7 cde & $1.3 \mathrm{e}$ & $6.5 \mathrm{~d}$ & $3.5 \mathrm{~cd}$ & $1.3 \mathrm{e}$ & $3.7 \mathrm{e}$ \\
\hline Norchip & $\ldots$ & $\ldots$ & $2.7 \mathrm{def}$ & $\ldots$ & $\ldots$ & $1.7 \mathrm{de}$ & $\ldots$ & -- & $\ldots$ & $1.5 \mathrm{f}$ \\
\hline Russet & & & & & & & & & & \\
\hline Norkotah & $7.0 \mathrm{a}$ & $8.0 \mathrm{bc}$ & 4.3 bcde & $5.3 \mathrm{c}$ & $8.0 \mathrm{bcd}$ & $1.3 \mathrm{e}$ & $7.0 \mathrm{~cd}$ & $1.5 \mathrm{ef}$ & $2.0 \mathrm{de}$ & $6.2 \mathrm{bcd}$ \\
\hline Means & 7.3 & 8.2 & 4.5 & 6.6 & 7.9 & 4.1 & 7.7 & 4.4 & 4.7 & 6.1 \\
\hline
\end{tabular}

${ }^{\mathrm{x}}$ Ratings are on a scale from 1 to 9 , where $9=$ no blight, $1=100 \%$ blight as described by Malcolmson (31); mean ratings are separated by Fisher's least significant difference test; ratings within columns followed by the same letter are not significantly different at $P \leq 0.05$.

${ }^{y}$ Greenhouse inoculations; plants were atomized with a suspension of 8,000 sporangia/ml and placed in a mist chamber for approximately $40 \mathrm{~h}$; ratings were taken periodically for 1 to 2 weeks.

${ }^{\mathrm{z}}$ Days following inoculation when the rating was taken. 
assays done at different times did not always have the same disease pressure. Typically, field results also vary from year to year because of the different severity of late blight epidemics. The importance of routinely using a set of known cultivars as standards in all experiments as a measure of the late blight epidemic potential, in order to impartially screen and compare germ plasm or fungicides, has previously been emphasized (10). Differences in disease severity among the plant age classes for specific cultivars also confirms previous reports of differences in susceptibility of potato cultivars with respect to age $(13,23,40,41)$.

Assessment of cultivars for late blight resistance in the whole plant greenhouse assays included a disease severity rating which was an overall plant assessment and an estimate of the percentage of the plant blighted, where $9=$ no blight and $1=$ $100 \%$ blighted. These ratings are similar to AUDPC values from field studies, in that they summarize resistance, the sum total of specific partial resistance components. For example, the number of lesions that develop, lesion growth rate, and latent period (time required from infection to sporulation) all contribute to the AUDPC and the parameters measured in the greenhouse ratings. The whole plant greenhouse assay evaluates infection efficiency for specific inoculum dosages, rate of lesion development, and growth. To a limited extent, sporulation capacity can be measured by manipulating the humidity levels.

The detached leaflet and leaf disk assays may not be useful for overall measurements of partial resistance. Colon et al. (6) reported that measuring individual components was very time consuming, and each component was influenced by the test conditions. Our results reflect a considerable change in reaction of some cultivars between experiments and variation in disease severity within experiments. These types of assays would require numerous repeated experiments and a large number of replications to verify results, both of which limit the usefulness in large segregating populations. Wenzel and Foroughi-Wehr (54) arrived at a similar conclusion when they reported that accurate measures of resistance to Phytophthora required 100 leaves, plant material as uniform as possible, and a large number of replicates.

One of the inherent risks in any screening evaluation is the presence of escapes or false designation of resistance when, in fact, there is inoculum failure. In the case of a detached leaf or disk in a plate, losing the inoculum is a particular danger. However, if disease escapes are a problem we would see that the most susceptible lines would sometimes have no blight. This occurred only to a limited extent in our study. The variation we recorded in these experiments likely resulted from the percentage of blight on each leaflet or leaf disk. The detached leaflet assay has proven effective for identifying virulence loci in specific $P$. infestans isolates, and separating germ plasm into distinct resistant or susceptible categories (Table 2). The detached leaflet or leaf disk assay may also be useful in examining infection efficiency under controlled environmental conditions or sporulation capacity on a known leaf area. Even though these laboratory assays may not be useful for overall disease evaluation, they would be helpful for as-

sessing individual components of partial resistance.

Occurrence of stem lesions is sometimes attributed to the new immigrant and metalaxyl-resistant $P$. infestans genotypes. Although potato plants may differ in stem resistance to late blight (17), not all researchers are in agreement (J. S. Niederhauser, personal communication). The stem assay described here does illustrate differences in resistance among the cultivars tested to the development of stem

Table 5. Comparison of detached leaflet and leaf disk laboratory assays for assessing potato foliage for resistance to late blight in twelve cultivars and two advanced potato selections

\begin{tabular}{|c|c|c|c|c|}
\hline \multirow{3}{*}{$\begin{array}{l}\text { Cultivar and advanced } \\
\text { potato selections }\end{array}$} & \multicolumn{4}{|c|}{ Percent colonization $^{x}$} \\
\hline & \multicolumn{2}{|c|}{ Detached leaflet $^{y}$} & \multicolumn{2}{|c|}{ Leaf $\operatorname{disk}^{z}$} \\
\hline & Test 1 & Test 2 & Test 1 & Test 2 \\
\hline Bzura & $\ldots$ & $2.1 \mathrm{ab}$ & $\cdots$ & $10.3 \mathrm{a}$ \\
\hline Brador & $0.0 \mathrm{a}$ & $0.0 \mathrm{a}$ & $0.0 \mathrm{a}$ & $0.0 \mathrm{a}$ \\
\hline Brodick & $\ldots$ & $0.0 \mathrm{a}$ & $\ldots$ & $0.0 \mathrm{a}$ \\
\hline A84118-3 & $17.9 \mathrm{ab}$ & $59.1 \mathrm{e}$ & $\ldots$ & 91.3 bcde \\
\hline Alpha & $\ldots$ & $25.7 \mathrm{~cd}$ & $\ldots$ & 90.0 bcde \\
\hline Elba & $15.0 \mathrm{ab}$ & $60.0 \mathrm{e}$ & $75.0 \mathrm{~d}$ & $98.8 \mathrm{de}$ \\
\hline COO83008-1 & $31.9 \mathrm{bc}$ & $32.3 \mathrm{~d}$ & $33.3 \mathrm{abc}$ & 82.2 bcde \\
\hline White Rose & $56.7 \mathrm{cde}$ & $12.3 \mathrm{abc}$ & $8.3 \mathrm{ab}$ & $75.0 \mathrm{~b}$ \\
\hline Kennebec & $88.8 \mathrm{f}$ & $19.4 \mathrm{bcd}$ & $47.5 \mathrm{bcd}$ & 91.7 bcde \\
\hline Russet Burbank & $82.5 \mathrm{ef}$ & $27.6 \mathrm{~cd}$ & $8.3 \mathrm{ab}$ & 96.9 cde \\
\hline Ranger Russet & $33.8 \mathrm{bc}$ & $63.1 \mathrm{e}$ & $\ldots$ & $100.0 \mathrm{e}$ \\
\hline Shepody & $51.8 \mathrm{~cd}$ & $56.7 \mathrm{e}$ & $25.0 \mathrm{abc}$ & 92.5 bcde \\
\hline Norchip & $\ldots$ & $35.0 \mathrm{~d}$ & $\ldots$ & 93.8 cde \\
\hline Russet Norkotah & $64.2 \mathrm{def}$ & $23.5 \mathrm{~cd}$ & $50.7 \mathrm{~d}$ & $98.5 \mathrm{de}$ \\
\hline Means & 45.9 & 30.6 & 28.6 & 73.5 \\
\hline
\end{tabular}

$x$ Percent colonization is based on the average of the visual estimate of 4 detached leaflets or 4 leaf disks (15-mm-diameter) per plate. Means within columns followed by the same letter are not significantly different $(P \leq 0.05)$ according to Fisher's least significant difference test.

${ }^{\mathrm{y}}$ Detached leaflet assay $=$ side lateral leaflets removed from greenhouse-grown plants (approximately 6 to 7 weeks old, just prior to flowering) and placed abaxial surface up in moist chambers, inoculated with $40 \mu \mathrm{l}$ of 4,000 sporangia/ml and incubated for 7 days at $20^{\circ} \mathrm{C}$ under $12 \mathrm{~h}$ light:dark.

${ }^{\mathrm{z}}$ Leaf disk assay = leaf disks (15-mm-diameter) cut from primary leaflet of four separate leaves and placed adaxial surface up in moist chambers, inoculated with $40 \mu \mathrm{l}$ of $4,000 \mathrm{sporangia} / \mathrm{ml}$, and incubated for 7 days at $20^{\circ} \mathrm{C}$ under $12 \mathrm{~h}$ light/dark.

Table 6. Differences in stem lesion length in 13 potato cultivars and 2 advanced selections challenged with a sporangial suspension of Phytophthora infestans ${ }^{\mathrm{y}}$

\begin{tabular}{lccc}
\hline & \multicolumn{3}{c}{ Stem blight lesion $(\mathbf{m m})^{\mathbf{z}}$} \\
\cline { 2 - 4 } Cultivar & Test $\mathbf{1}$ & Test 2 & Test 3 \\
\hline Bzura & $0.0 \mathrm{a}$ & $2.4 \mathrm{a}$ & $0.0 \mathrm{a}$ \\
Brador & $0.0 \mathrm{a}$ & $0.0 \mathrm{a}$ & $0.0 \mathrm{a}$ \\
Brodick & $0.0 \mathrm{a}$ & $0.0 \mathrm{a}$ & $0.0 \mathrm{a}$ \\
A84118-3 & $28.5 \mathrm{~cd}$ & $44.4 \mathrm{bc}$ & $14.7 \mathrm{ab}$ \\
Alpha & $\ldots$ & $\ldots$ & $50.0 \mathrm{cde}$ \\
Elba & $0.0 \mathrm{a}$ & $0.0 \mathrm{a}$ & $58.7 \mathrm{de}$ \\
C0083008-1 & $2.3 \mathrm{ab}$ & $4.2 \mathrm{a}$ & $27.3 \mathrm{bc}$ \\
White Rose & $43.6 \mathrm{de}$ & $2.1 \mathrm{a}$ & $0.0 \mathrm{a}$ \\
Kennebec & $26.8 \mathrm{~cd}$ & $8.0 \mathrm{a}$ & $46.3 \mathrm{bc}$ \\
Russet Burbank & $17.6 \mathrm{abc}$ & $34.7 \mathrm{bc}$ & $33.0 \mathrm{bc}$ \\
Ranger Russet & $55.1 \mathrm{a}$ & $38.8 \mathrm{bc}$ & $57.7 \mathrm{de}$ \\
Shepody & $35.3 \mathrm{cde}$ & $39.3 \mathrm{bc}$ & $21.7 \mathrm{ab}$ \\
Red LaSoda & $31.3 \mathrm{cde}$ & $52.5 \mathrm{c}$ & $70.0 \mathrm{e}$ \\
Norchip & $\ldots$ & $\ldots$ & $35.7 \mathrm{bcd}$ \\
Russet Norkotah & $19.0 \mathrm{abc}$ & $22.0 \mathrm{bc}$ & $29.7 \mathrm{bc}$ \\
Means & 20.1 & 20.5 & 29.7 \\
\hline
\end{tabular}

y Stem cuttings $100-140 \mathrm{~cm}$ in length were taken from greenhouse-grown plants (6-8 weeks old) and placed in nutrient solution (14). Filter paper squares with sporangia suspension (16-18,000 sporan$\mathrm{gia} / \mathrm{ml}$ ) were placed on the stem. Cuttings were incubated for 7 days at $20^{\circ} \mathrm{C}$ with $12 \mathrm{~h}$ light:dark cycle.

${ }^{z}$ Means of three cuttings were separated using Fisher's least significant difference test, means followed by the same letter in the same column are not significantly different at $P \leq 0.05$. 
Table 7. Correlation coefficients for the relationships between area under the disease progress curve (AUDPC) measured in the field in 1996, and disease ratings in greenhouse and laboratory assays using 13 potato cultivars and 2 advanced selections for foliage resistance to Phytophthora infestans

\begin{tabular}{|c|c|c|c|c|c|c|c|c|}
\hline \multirow[b]{2}{*}{ Plant age classes } & \multicolumn{4}{|c|}{ AUDPC $^{x}$ and greenhouse assays ${ }^{y}$} & \multicolumn{4}{|c|}{ AUDPC and laboratory assays ${ }^{z}$} \\
\hline & June & July & August & September & Assay & Test 1 & Test 2 & Test 3 \\
\hline 4 to 6 weeks & $-0.82^{*}$ & $-0.75^{*}$ & $-0.57^{*}$ & $\ldots$ & Detached leaflet & $0.68^{*}$ & 0.49 & . \\
\hline 7 to 8 weeks & $-0.88 *$ & -0.28 & $-0.84 *$ & $\ldots$ & Leaf disk & 0.44 & $0.77 *$ & $\ldots$ \\
\hline 9 weeks & $\ldots$ & $-0.85^{*}$ & $-0.95^{*}$ & $-0.74^{*}$ & Stem & $0.62 *$ & 0.56 & $0.52 *$ \\
\hline 11 weeks & $\ldots$ & $\ldots$ & $-0.84 *$ & $\ldots$ & & & & \\
\hline
\end{tabular}

${ }^{\mathrm{x}}$ Correlation coefficients are from comparisons with the ranked means of the field AUDPC (see Table 3 ). Numbers followed by an asterisk are significant at $P \leq 0.05$.

${ }^{\mathrm{y}}$ Greenhouse assays utilized a disease rating scale of $1=100 \%$ disease and $9=$ no disease, described by Malcolmson ( 31$)$ for different age classes (weeks after planting) of potatoes (see Table 4).

${ }^{\mathrm{z}}$ Laboratory assays measured percent colonization of detached leaflets, leaf disks, and stem lesion length (see Tables 5 and 6 ); numbers followed by an asterisk were significant at $P \leq 0.05$.

blight. A majority of cultivars developed stem lesions to our 95WWA $P$. infestans isolate. Several replications of this assay may be necessary to accurately assess resistance of potato stems.

We found significant differences between tests within each assay, not necessarily in the final resistance ranking of the cultivars tested but in how quickly the disease progressed and the final disease severity. The way in which temperature influences the rate of epidemic development and changes the resistance response needs to be further defined for greenhouse and laboratory assays. Knowledge in these areas will improve environmental controls for assay conditions, thus improving the quality of the assay. Cultivars Elba and Ranger Russet might be good candidates for studies that explore environmental effects on the expression of late blight resistance, because their disease rankings tend to fluctuate in different field and laboratory assays.

The greenhouse whole plant inoculation is useful for studies of inheritance of resistance, identification of resistance components and for choosing potential germ plasm to be used as parents $(1,2,3,51)$. Greenhouse-grown Solanum progeny could be selected from $P$. infestans-challenged plants based on percent blight or a rating scale, thus eliminating the need for largescale field tests. Challenges with complex $P$. infestans genotypes or isolates known to colonize a wide range of potato genotypes in these laboratory assays would help avoid selection of single R-gene resistance.

This study confirms previous reports that greenhouse studies on plants inoculated 7 to 11 weeks after planting can reliably aid screening efforts to assess germ plasm for resistance to late blight. Inoculations at or near flowering corresponded best with overall 1996 field AUDPC ratings when there was a high amount of disease in the test. The greenhouse inoculations 7 to 11 weeks after planting also provided a wide range of disease responses for separation into distinct resistant classes: highly susceptible, moderately susceptible, moderately resistant, and resistant. Greenhouse and laboratory assays cannot replace the value of evaluating germ plasm for foliar resistance to late blight under field conditions. If repeated under controlled environmental conditions, they can help expedite the selection process and allow for evaluation of the partial resistance components needed in potato cultivars at this time.

\section{ACKNOWLEDGMENTS}

We thank Charles Brown, Dennis Corsini, Dennis Johnson, and Roland Line for providing comments and suggestions regarding this manuscript, and Marc Evans, Larry Madden, Nancy Callahan, and Babette Gundersen for statistical and technical support.

\section{LITERATURE CITED}

1. Bradshaw, J. E., Stewart, H. E., Wastie, R. L., Dale, M. F. B., and Phillips, M. S. 1995. Use of seedling progeny tests for genetical studies as part of a potato (Solanum tuberosum subsp. tuberosum) breeding programme. Theor. Appl. Genet. 90:899-905.

2. Caligari, P. D. S., Mackay, G. R., Stewart, H. E., and Wastie, R. L. 1984. A seedling progeny test for resistance to potato foliage blight (Phytophthora infestans (Mont.) de Bary). Potato Res. 27:43-50.

3. Caligari, P. D. S., Mackay, G. R., Stewart, H. E., and Wastie, R. L. 1985. Confirmatory evidence for the efficacy of a seedling progeny test for resistance to potato foliage blight (Phytophthora infestans (Mont.) de Bary). Potato Res. 28:439-442.

4. Carnegie, S. F., and Colhoun, J. 1982. Susceptibility of potato leaves to Phytophthora infestans in relation to plant age and leaf position. Phytopathol. Z. 104:157-167.

5. Colon, L. T., and Budding, D. J. 1988. Resistance to late blight (Phytophthora infestans) in ten wild Solanum species. Euphytica S:7786.

6. Colon, L. T., Budding, D. J., Keizer, L. C. P., and Pieters, M. M. J. 1995. Components of resistance to late blight (Phytophthora infestans) in eight South American Solanum species. Eur. J. of Plant Pathol. 101:441-456.

7. Davila, E. 1964. Late blight infection of potato tubers. Am. Potato J. 41:103-112.

8. Deahl, K. L., and Inglis, D. A. 1995. Occurrence of metalaxyl-insensitive Phytophthora infestans on Solanum sarachoides in northwestern Washington. Plant Dis. 79:540.

9. Deahl, K. L., Inglis, D. A., and DeMuth, S. P. 1993. Testing for resistance to metalaxyl in Phytophthora infestans isolates from northwestern Washington. Am. Potato J. 70:779795.

10. Dowley, L. J., O'Sullivan, E., and Kehoe, H. W. 1991. Development and evaluation of blight resistant potato cultivars. Pages 373382 in: Phytophthora. J. A. Lucas, R. C. Shattock, S. S. Shaw, and L. R. Cooke, eds.
Cambridge University Press, Cambridge.

11. Flor, H. H. 1955. Host parasite interaction in flax rust-its genetics and other implications. Phytopathology 45:680-685.

12. Flor, H. H. 1971. Current status of the genefor-gene concept. Ann. Rev. Phytopathol. 9:275-296.

13. Fry, W. E., and Apple, A. E. 1986. Disease management implications of age-related changes in susceptibility of potato foliage to Phytophthora infestans. Am. Potato J. 63:4755.

14. Gallegly, M. E. 1968. Genetics of the pathogenicity of Phytophthora infestans. Annu. Rev. Phytopathol. 6:375-396.

15. Geary, B., Johnson, D. A., Cummings, T., and Miller, J. S. 1996. Redistribution of air applied fungicides in potato canopies. (Abstr.) Am. Potato J. 73:356.

16. Gisi, U., and Cohen, Y. 1996. Resistance to phenylamide fungicides: A case study with Phytophthora infestans involving mating type and race structure. Annu. Rev. Phytopathol. 34:549-572.

17. Glendinning, D. R. 1989. Late blight resistance in the British neo-tuberosum potato population. Potato Res. 32:321-330.

18. Goodwin, S. B., Sujkowski, L. S., Dyer, A. T. Fry, B. A., and Fry, W. E. 1995. Direct detection of gene flow and probable sexual reproduction of Phytophthora infestans in northern North America. Phytopathology 85:473-479.

19. Goodwin, S. B, Sujkowski, L. S., and Fry, W. E. 1996. Widespread distribution and probable origin of resistance to metalaxyl in clonal genotypes of Phytophthora infestans in the United States and western Canada. Phytopathology 86:793-800.

20. Goodwin, S. B., Sujkowski, L. S., and Fry, W. E. 1995. Rapid evolution within clonal lineages of the potato late blight disease fungus. Phytopathology 85:669-676.

21. Goth, R., and Keane, J. 1996. Use of detached leaf assay for evaluating late blight reactions of potato and tomato. (Abstr). Am. Potato J. 73:357.

22. Guzmàn, N. J. 1964. Nature of partial resistance of certain clones of three Solanum species to Phytophthora infestans. Phytopathology 54:1398-1404.

23. Hodgson, W. A. 1961. Laboratory testing of the potato for partial resistance to Phytophthora infestans. Am. Potato J. 38:259264.

24. Inglis, D. A., Johnson, D. A., Legard, D. E., Fry, W. E., and Hamm, P. B. 1996. Relative resistances of potato clones in response to new and old populations of Phytophthora infestans. Plant Dis. 80:575-578.

25. James, R. V., and Fry, W. E. 1983. Potential for Phytophthora infestans populations to adapt to potato cultivars with rate-reducing resistance. Phytopathology 73:984-988.

26. Kadish, D., Grinberger, M., and Cohen, Y. 
1990. Fitness of metalaxyl-sensitive and metalaxyl-resistant isolates of Phytophthora infestans on susceptible and resistant potato cultivars. Phytopathology 80:200-205.

27. Knutson, K. W. 1962. Studies on the nature of field resistance of the potato to late blight. Am. Potato J. 39:152-161.

28. Kroll, R. E., and Eide, C. J. 1981. Effect of inoculum concentration of Phytophthora infestans on potato late blight. Am. Potato J. 58:153-161.

29. Lacey, C. N. D., Jellis, G. J., Starling, N. C., and Currell, S. B. 1987. A joint cyst nematode/late blight test for early generation screening of potato clones. Pages 81-83 in: The Production of New Potato Varieties: Technological Advances. Cambridge University Press, Cambridge.

30. Leonards-Schippers, C., Gieffers, W., SchaferPregl, R., Ritter, E., Knapp, S. J., Salamini, F., and Gebhardt, C. 1994. Quantitative resistance to Phytophthora infestans in potato: a case study for QTL mapping in an allogamous plant species. Genetics 137:67-77.

31. Malcolmson, J. F. 1976. Assessment of field resistance to blight (Phytophthora infestans) in potatoes. Trans. Br. Mycol. Soc. 67:321-360.

32. Malcolmson, J. F., and Killick, R. J. 1980. Breeding values of potato parents for field resistance to late blight measured by whole seedlings. Euphytica 29:489-495.

33. Miller, J. S., Johnson, D. A., and Hamm, P. B. 1996. Aggressiveness of Phytophthora infestans isolates in the Pacific Northwest. (Abstr.) Phytopathology 85:1127.

34. Nilsson, B. A. 1981. Component analysis of general resistance to Phytophthora infestans in clones from the Colombian potato collection. Potato Res. 24: 239-244.

35. Parlevliet, J. E. 1979. Components of resistance that reduce the rate of epidemic development. Annu. Rev. Phytopathol. 17:203-222.

36. Pavek, J. J. 1987. Some interesting aspects of recent and expected developments in potato breeding in North America (Canada and the United States of America). Acta Hortic.
213:61-65.

37. Rivera-Peña, A. 1990. Wild tuber-bearing species of Solanum and incidence of Phytophthora infestans (Mont.) de Bary on the western slopes of the volcano Nevado de Toluca. 5. Type of resistance to $P$. infestans. Potato Res. 33:479-486.

38. Schumann, G., and Thurston, H. D. 1976 Foliar infection of potato by Phytophthora infestans inhibited by two insecticides. Plant Dis. Rep. 60:734-735.

39. Simmonds, N. W., and Wastie, R. L. 1987. Assessment of horizontal resistance to late blight of potatoes. Ann. Appl. Biol. 111:213221.

40. Stewart, H. E. 1990. Effect of plant age and inoculum concentration on expression of major gene resistance to Phytophthora infestans in detached potato leaflets. Mycol. Res. 94:823-826.

41. Stewart, H. E.; Taylor, K., and Wastie, R. L. 1983. Resistance to late blight in foliage (Phytophthora infestans) of potatoes assessed as true seedlings and as adult plants in the glasshouse. Potato Res. 26:363-366.

42. Swiezynski, K. M., Domanski, L., Sieczka, M. T., and Zarzycka, H. 1993. Specific resistance to Phytophthora infestans in the potato. Genet. Pol. 34:327-336.

43. Swiezynski, K. M., Sieczka, M. T., Sujkowski, L. S., Zarzycka, H., and ZimnochGuzowska, E. 1991. Resistance to Phytophthora infestans in potato genotypes originating from wild species. Plant Breeding 107:28-38.

44. Tai, G. C. C., and Hodgson, W. A. 1975. Estimating general combining ability of potato parents for field resistance to late blight. Euphytica 24:285-289.

45. Tarn, T. R., Tai, G. C. C., Murphy, A. M., DeJong, H., Platt, H. W., Bagnall, R. H., Arsenault, W. J., Thorpe, J. H. E., Young, D. A., and Davies, H. T. 1995. AC Brador: A new late-maturing cultivar with a high degree of field resistance to late blight. Am. Potato J. 72:401-408.
46. Thurston, H. D. 1971. Relationship of general resistance: Late blight of potato. Phytopathology 61:620-626.

47. Thurston, H. D., Plaisted, R. L., Brodie, B. B. Jones, E. D., Loria, R., Halseth, D., and Siec zka, J. G. 1985. Elba: A late maturing, blight resistant potato variety. Am. Potato J. 62:653 656.

48. Tooley, P. W. 1990. Variation in resistance to Phytophthora infestans among 21 Solanum verrucosum plant introductions. Am. Potato J. 67:491-498.

49. Tooley, P. W.; Sweigard, J. A., and Fry, W. E. 1986. Fitness and virulence of Phytophthora infestans isolates from sexual and asexual populations. Phytopathology 76:1209-1212

50. Toxopeus, H. J. 1956. Reflections on the origin of new physiologic races in Phytophthora infestans and the breeding for resistance in potatoes. Euphytica 5: 221-237.

51. Umaerus, V. 1969. Studies on field resistance to Phytophthora infestans 2. A method of screening young potato seedlings for field resistance to $P$. infestans. Z. Pflanzenzuchtung 61:167-194.

52. Umaerus, V., Umaerus, M., Erjefält, L, and Nilsson, B. A. 1983. Control of Phytophthora by host resistance: problems and progress. Pages 315-326 in: Phytophthora Its Biology, Taxonomy, Ecology, and Pathology. D. C. Erwin, S. Bartnicki-Garcia, and P. H. Tsao, eds. American Phytopathological Society, St. Paul, MN.

53. Wastie, R. L. 1991. Breeding for resistance. Pages 193-223 in: Advances in Plant Pathology Phytophthora infestans, the Cause of Late Blight of Potato V7. D. S. Ingram and P. H. Williams, eds. Academic Press, New York.

54. Wenzel, G., and Foroughi-Wehr, B. 1990 Progeny tests of barley, wheat, and potato regenerated from cell cultures after in vitro selection for disease resistance. Theor. Appl. Genet. 80:359-365.

55. Wilcoxson, R. D. 1981. Genetics of slow rusting in cereals. Phytopathology 71:989993. 